\title{
THE PROPOSED CORPORATION CODE OF THE PHILIPPINES
}

\author{
By Sulpicio Guevara
}

The Philippine Corporation Law was enacted way back in 1906, at a time when the Philippines was still under the American sovereignty. Its concept was therefore American in origin and based on American corporate practices. Being basically American-oriented, the decisions of the United States Supreme Court and of the American state courts continue to be cited as authorities in its construction, interpretation, and application.

The present Corporation Law, being more than half a century old, although some of its provisions have subsequently been amended by the Philippine law-making body, there is a felt need for a more up-to-date corporation law with features embodying provisions relevant to the new trends in business practices.

The first real attempt to completely overhaul the present law and produce an entirely new corporation law, intended to supplant the present law of 1906 vintage, was originally conceived by the author of this article who, upon his joining the U.P. Law Center ${ }^{1}$ in 1970, suggested the undertaking of a research project on corporation law. The proposed research project was promptly approved by the then Director of the U.P. Law Center, Prof. Crisolito S. Pascual, who was later elevated as one of the Associate Justices of the Court of Appeals of the Philippines.

\section{The Corporation Law Codification Committee}

It was not, however, until October 25, 1971 that a Corporation Law Codification Committee was formally organized headed by the author of this article as Chairman and Project Head, with two other members appointed upon the suggestion of the chairman; namely, Prof. Maria Clara L. Campos, professor of commercial law of the College of Law, University of the Philippines, and Atty. Rosa Maria J. Bautista, a senior member of the research staff of the U.P. Law Center. The Committee may be said to have begun its work on October 26, 1971. A preliminary outline of topics was prepared and distributed by the Project Head among the members of the Committee. These topics, however, were improved upon during the progress of the work. The principal topics worked on by the members of the Committee are those appearing in the Final Draft, to wit: General Provisions; Incorporation and Organization of Private Corporations; Directors or Trustees and Corporate Officers; Powers of Corporation; By-laws; Meetings; Stock and Stockholders (which includes the sub-topics of Subscription, Transfer of Stock and Derivative Suits); Corporate Books and Records; Merger and Consolidation; Monopolies and Prohibited Acquisitions; Appraisal Right; Close Corporations; Non-profit Corporations; Special Corporations; Philippine Corporation Community Improvement Fund; Dissolution; Foreign Corporations; and Miscellaneous Provisions.

1 The U.P. Law Center was created as a unit of the University of the Philippines System in 1964 (Republic Act No. 3870) see VRU 1975, p. 309. 


\section{The Draft Codes}

The first preliminary draft Code was finished on October 25, 1972 and copies thereof were distributed among, and jointly discussed by, all members of the Codification Committee, including the Director of the Law Center.

A second revised draft Code was later prepared, and sufficient copies thereof were mimeographed and distributed among law professors and practitioners, business executives, and officials of government agencies who have something to do with the operation of private corporations, as well as with the development and progress of Philippine law, like the Securities and Exchange Commission, the National Economic Development Authority, the Board of Investments, the Department of Trade and Commerce, the Integrated Bar of the Philippines, and similar others. After giving these knowledgeable persons and agencies sufficient time to read and study the proposed draft Code, open forums were held on several occasions in the U.P. Law Center in which oral and written comments were given by the participants and considered by the Committee. The comments and discussions proved very enlightening, and a few of the original draft provisions were accordingly amended by the Committee. But in the main, the original draft remains substantially intact as drafted by the Codification Committee.

The draft Corporation Code was finalized on March 31, 1973 and mimeographed copies thereof were sold at nominal price to the general public. Even after the termination of the open forums held on several occasions, belated written comments and suggestions from every quarter continued to pour into the Law Center, some of which were well taken. So, the Project Head, in consultation with the members of the Committee, tried to improve further the language of the draft as amended.

One June 6, 1974, the Final Draft and two extra copies were sent to the Office of the President of the Republic of the Philippines for promulgation into law. Inasmuch as no official action has been heard from the Office of the President for sometime, the Project Head again personally went over the Final Draft, and after discovering a few provisions which could still stand improvement, especially in phraseology and style, a Final Revised Draft was prepared.

One original copy and two extra copies thereof were again submitted to the Office of the President of the Republic of the Philippines on November 20, 1974. This is the Draft Code (Final Revised Draft) now awaiting promulgation into law, which if approved, will revolutionize the concept of private corporations in the Philippines.

\section{Salient Features of the Proposed Code}

Some significant changes effected by the proposed Code are as follows:

1. The distinction between private and public corporations is made more definite. (Sec. 3)

2. All corporators of stock corporations must be stockholders or owners of stock. (Sec. 6) 
3. Government-owned or controlled corporations may be incorporated by virtue of the law creating them, without need of individual incorporators. (Sec. 8)

4. Bearer shares may now be issued by stock corporations under certain conditions. (Sec. 9)

5. Shares of stock may be classified as non-transferable for the purpose of complying with constitutional or other valid administrative requirements. (Sec. 10)

6. Issuance and redemption of redeemable shares have been clarified. (Sec. 11)

7. Any number of incorporators not less than five may incorporate. (Sec. 13)

8. A business corporation may be incorporated for any lawful purpose or purposes and can have any number of secondary purposes as may be necessary to accomplish the main purpose or purposes of its incorporation. (Sec. 13)

9. Private corporations may be incorporated for any period as may be stated in its articles of incorporation. (Sec. 14)

10. The minimum amount of capital stock for corporate form of organization is ten thousand $(=10,000)$ pesos; those with less amount may only be organized in some other form of business organization recognized by law. (Sec. 15)

11. The minimum subscription and amount to be paid for purposes of incorporation shall be twenty-five $(25 \%)$ percent and twenty-five $(25 \%)$ percent, respectively. All subscriptions to the capital stock of a stock corporation are required to be paid in full within five (5) years from date of subscription, without need of call. (Sec. 16)

12. All articles of incorporation submitted for filing with the Securities and Exchange Commission must be either in English or Filipino. (Sec. 17)

13. Interlocking directorships are regulated. (Secs. 41, 116)

14. The liability of incorporators who assume to act as corporation without due incorporation is spelled out. (Sec. 24)

15. The number of directors or trustees, except in the cases otherwise expressly provided by the Code, may be any number not less than five (5). (Sec. 28)

16. At least one-half $(1 / 2)$ of the directors or trustees (not only two as required by the present law) must be residents of the Philippines. (Sec. 28)

17. Unless otherwise required by the articles of incorporation or the by-laws, a director of a stock corporation need not own any stock. (Sec. 28)

18. Employee representation in the Board of Directors of stock corporations is allowed, if so provided in the articles of incorporation or in the by-laws. (Sec. 30)

19. Persons convicted of offenses involving moral turpitude are disqualified to become corporate directors or trustees. (Sec. 35)

20. Compensation, other than per diems may not be lawfully granted a director, except when approved by the stockholders representing at least $2 / 3$ of the outstanding capital stock at a stockholders' meeting duly called for the purpose, and provided the total compensation shall not exceed ten $(10 \%)$ percent of the net profits, after tax, of the corporation in any one year. (Sec. 38)

21. Private corporations are prohibited to give contributions to campaign funds of any political party. (Sec. 45)

22. Stock corporations, other than close corporations as defined in this Code, are prohibited from retaining earnings in excess of one hundred $(100 \%)$ percent of their paid-in capital stock, unless justified by definite, duly approved expansion projects or programs. (Sec. 53)

23. Power of corporations to enter into "service or management" contract with a foreign citizen or entity is expressly recognized. (Sec. 54) 
24. Stock certificates are practically given full negotiability. (Sec. 86)

25. The generally accepted principles regarding derivative suits have been adopted. (Secs. 98-102)

26. A special chapter on "merger and consolidation" or corporations is especially provided for. (Secs. 109-113)

27. A special chapter on "Monopolies and consolidation" of corporations is especially provided for. (Secs. 109-113)

28. Method of appraisal of the value of shares of a withdrawing stockholder in proper cases is spelled out. (Sec. 119)

29. A special chapter on "Close Corporations" is provided for. (Secs. 127-132)

30. The right to vote by proxy in non-profit corporations may be denied if so expressly provided in the Articles of Incorporation or in the by-laws. (Sec. 137) In other corporations, the rule is that provided for in Sec. 69, recognizing the right to vote by proxy.

31. Educational institutions shall operate as non-profit corporations, granting them sufficient time to comply with the new requirements of the Code. (Secs. 150-154; 204)

32. Special provisions on "Special Corporations" are included, introducing the idea of "Community Development Corporation", which may include cooperatives of the "Samahang Nayon"2 concept. (Secs. 164-167)

33. The most significant feature of the proposed Corporation Code is the requirement that all business corporations must contribute to a common fund, called the PCCI Fund (Private Corporation Community Improvement Fund) one $(1 \%)$ percent of their annual net profits, after tax, to be administered by a Board of Trustees, elected by 200 biggest contributors to the Fund, to be used solely and exclusively to support any social and economic project which will redound to the direct benefit of any community in the Philippines. (Secs. 168-173)

34. No foreign corporation shall be allowed to transact business in the Philippines unless the law of the country of its incorporation allows Filipino citizens and corporations the equal right to do business therein. (Sec. 183)

35. The Securities and Exchange Commission is granted ample powers to enable it to make adequate supervision over the operation and activities of private corporations. (Secs. 197-200; 194; 183; 177; 171; 167; 166; 117; 112; 73; 49; 47; $34 ; 21 ; 20 ; 17)$

36. A domestic corporation may engage in any purpose or purposes as stated in its articles of incorporation (Sec. 13); but a foreign corporation authorized to transact business in the Philippines may engage only for such purpose or purposes as authorized in its certificate of authority. (Secs. $183 ; 190$ )

37. Private corporations in appropriate cases may be criminally prosecuted as such. (Sec. 201)

One of the provisions of the Corporation Code Draft which became the concerted object of criticism (not on the part of those who participated in the discussion notwithstanding the fact that many of them represented "big business"; but on the part of some twenty out of 148 members of the Philippine Business for Social Progress (PBSP), is Section 168 of the Final Draft. Their criticisms are similarly and substantially worded; namely, that to convert into a legal obligation

2 Literally "Samahang Nayon" means an association of rural folks, particularly farmers. 
that which they are now doing on a voluntary basis ${ }^{3}$ would allegedly destroy their initiative and perhaps dampen their social spirit. This argument, to say the least, is naive. On the contrary, they should now be happier because instead of only 148 business corporations contributing for social and economic progress, all of the remaining corporations who did not join their association (PBSP) will now be obliged to join and corporate with the social objective of the Philippine Business for Social Progress. There are 52,303 domestic corporations and 605 foreign corporations doing business in the Philippines. Of these only 148 are members of the Philippine Business for Social Progress who volunteered to contribute to their common fund. Progress of Philippine communities, especially the barrios cannot depend upon the uncertainty of voluntary corporate decisions. A new concept of accelerated progress has been announced by the President of the Philippines. which is, that of spreading the benefits of capitalism into the welfare state, or in the words of the President, "to marry capitalism to the welfare state". (See the BulletinToday, August 4, 1973). The fact that the Philippine Business for Social Progress composed of some 148 corporations is now doing the very same objective sought to be attained by Sections 168-173 of the proposed Code disproves their allegation that they would become less enthusiastic if obliged by law; such an argument appears to be inconsistent or self-contradictory. The allegation that voluntariness in solving community problems would give more room for "innovative and diverse approach" is not in conflict with the idea of the proposed Code, because the management and disposal of the PCCI Fund shall still remain under the management and control of the business corporations themselves, with the added proviso that their social and economic plans and programs shall, as much as possible, be coordinated or harmonized with the plans and policies of the Government.

This will do away with unnecessary wastage and duplication of government and private efforts aimed at community development and progress, thus resulting in savings for both sectors, and in more meaningful and better planned programs for community development.

Anent the further objection that this particular provision of the Code is discriminatory because while only business corporations have been singled out, others like partnerships and individuals are not similarly obliged, when all of them are beneficiaries of community improvements. It must be remembered that this is a Code governing private corporations, not partnerships or individuals, and even if the latter have the equal right to engage in business as private corporations, yet there is reason for imposing only on private corporations this special obligation, because they, unlike partnerships and individuals, are created by law; hence, inasmuch as private corporations owe their legal existence to the law, they may be obliged to serve the end and purpose of the law that created them, - public welfare.

Moreover, the contributions being made or already made by the members of the Philippines Business for Social Progress will not at all be prejudiced or duplicated, because the proposed Code (Sec. 172) provides that among the powers of the Board of Trustees to be elected by the 200 biggest contributors to the Fund is to

\footnotetext{
3 The P.B.S.P. is a voluntary association of Philippine corporations (numbering about 148) which agreed voluntarily to involve themselves in social development, an idea based on the idea of "Dividendo Voluntario para la Comunidad" initiated by Venezuelan businessmen and industrialists some 12 years ago.
} 
"coordinate the activities of any other existing voluntary or extra-legal association (or associations hereafter to be created) with similar objectives as those of the PCCI Fund with the view either of bringing or integrating into the fund the financial resources of said association or associations and crediting the business corporations with their contributions payable under this Code, or of working out a plan to attain unity and harmony in their common objective of social and economic progress of the community". In other words, whether under the present voluntary set-up of the Philippine Business for Social Progress or under the compulsory provision of the proposed Code, the business corporations themselves will continue to be in control and management of their own funds, and the proposed provisions will not at all affect their "innovative and various approaches" to the solution of community problems, except that, as stated before, their plans should be coordinated with national or governmental programs. The other changes effected by the proposed Corporation Code have generally been considered by those who took part in the open forums as constituting definite improvements on the present Corporation Law, Act. No. 1459 as amended.

\section{The Proposed Corporation Code is Substantially Filipino in Thought and Philosophy}

Unlike the present Corporation Law of 1906, the proposed Code was conceived by Filipinos to remedy wrong practices peculiar to the Philippine environment.

One of the evil practices of corporate directors is to approve at the end of every fiscal year a resolution granting to themselves a certain percentage of the net profits of the corporation as "bonuses" for their alleged efficient management of the affairs of the corporation. While the idea may be justified on the ground of rewarding good work done, yet the practice of corporate directors of granting bonuses to themselves without the approval of the stockholders in general seems to be objectionable on moral grounds. Hence, Section 38 of the proposed Corporation Code provides as follows:

"Sec. 38. Compensation of directors. - In the absence of any provision fixing their compensation in the by-laws or in a resolution adopted by a vote of the stockholders, the directors shall not receive any compensation as such. Any compensation other than per diems, may be granted to such directors by the vote of the stockholders representing at least two-third of the outstanding capital stock at a stockholders' meeting duly called for the purpose; Provided, That the total amount of all such compensation shall not exceed ten $(10 \%)$ percent of the net profits of the corporation, after payment of taxes, in any one (1) year."

Again, the idea of corporate management in the Philippines has been influenced very much by the American concept which is, that to the stockholders belong the right to receive dividends and to the directors alone belong the right to manage the corporation. The proposed Corporation Code proposes to change this American-oriented concept of corporate management by introducing the idea of giving the stockholders a share in the management of corporate affairs. The first draft of the Codification Committee made such right mandatory. But due to strong opposition on the part of representatives from big businesses, the Committee toned down the original draft provision, so that it now reads as follows: 
"Sec. 30. Employees's representation in the Board. - When the number of employees of a stock corporation below supervisory or management level exceeds 100, the said corporation by its articles of incorporation or by-laws may give them the right to elect from among themselves one representative to the Board of Directors. Such employees' representative need not be a stockholder unless so required by the articles of incorporation or by-laws, and, when duly elected, shall have the right to sit in all meetings of the board and shall enjoy all the powers, prerogatives, rights, and shall comply with all the duties and functions of a regular member of the board; Provided, however, That any compensation, other than per diems, granted to him as such director, shall inure in equal shares to the benefit of all the employees whom he represents.

The by-laws may prescribe the procedure for conducting the election of said employees' representative and such other rules as may be necessary to implement the provisions of this section."

But even with this toned-down provision, the seed or idea of employee representation in corporate management shall have been planted if the Code is promulgated into law, and may eventually blossom into fruition as the standard practice of corporate management in the Philippines.

To compensate the corporation for the added obligation of contributing $1 \%$ of their net profits, after income tax, to a special fund for helping eradicate rural poverty, the proposed Corporation Code eliminated the restrictive provision of the present law [as construed by the Supreme Court in the case of Uy Suliong v. Director of Commerce, 40 Phil. 541 (1919)] which limits the business corporation to state only one principal purpose in its articles of incorporation and to do only subsidiary acts related to or necessary to the accomplishment of such main purpose. But under the proposed Code, a business corporation may engage in as many principal business purposes as it may like to engage in and may be capable of accomplishing (Sec. 13, Proposed Code), just like an individual, so long as the various purposes stated in the articles are not immoral or illegal or violative of existing laws against monopolies. There is certainly nothing wrong or immoral in allowing a business corporation to exploit various business possibilities which will enable it to exist with greater prosperity. In other words, while the proposed Code has imposed added responsibility on the corporation to become unwilling partners of the government in easing rural poverty, it has at the same time invested it with greater powers and freedom in devising ways and means to enable it to be of greater service not only to its stockholders but to the State. 


\section{REFERENCES}

"Answers to United Nations Questionnaire. Persons considered to be born out of wedlock." Typescript copy from Attorney General's Office.

Baker, T. and Bird, M.

"Urbanization and the position of women" in special number on Urbanism in West Africa, ed. K. Little, Sociological Review, Vol. 7, No. 1, New Series 1959.

Bangurah, J.

"Born to be outcasts". Flamingo, Sierra Leone. Vol. 4 No. 11, August 1965 Edition.

Barnes, J. A.

"The politics of law" in Man in Africa, ed. M. Douglas and P. Kaberry, London, 1969.

Collier, G.

Crabtree, A. I.

Sierra Leone - Experiment in Democracy in an African Nation. New York, 1970.

"Marriage and family life among educated Africans in the urban areas of the Gold Coast". Unpublished M.Sc. Thesis, London University, 1950.

DAILY MAIL

Harrell-Bond, B. E. 31 August, 1965, 3 September 1965.

"Modern marriage in Sierra Leone: a study of the professional group." Mouton, 1975 (forthcoming).

Harrell-Bond, B. E.

"Survey research in a study of marriage" in Solving Problems of Survey Research in Africa, ed. O'Barr Spain and Sessler, Chicago, 1972.

Harrell-Bond, B. E.

"Some influences on attitudes about family limitation and on the use of contraceptives among the professional group in Sierra Leone' in Population Growth - Socio-economic Change in West Africa ed J. C. Caldwell, N. O. Addo, S. K. Gaise, A. Igun, P. O. Olusanga, Columbia University Press 1974.

Izzett, $\mathbf{A}$.

"Family life among the Yoruba in Lagos, Nigeria" in Social Change in Modern Africa, ed. A. W. Southall, London, 1961.

Jellicoe, G.

Unpublished London University Diploma in Social Anthropology thesis, 1955.

Kilson, M.

Political Change in a West African State. Cambridge, Mass., 1966.

Koelle, S. W.

Polyglotta Africana, London, 1851.

Laws of Sierra Leone, 1960 Edition.

Little, K. L.

The Mende of Sierra Leone (First Edition, 1951). London, 1967.

Little, K. L. and Price, $\dot{A}$.

Moore, S. F.

Peterson, J.

Pospisil, L.

Saario, U. U.

Smart, H. M. J.

"Some trends in modern marriage among West Africans". Africa, Vol. 37, No. 4, October 1967.

"Law and Anthropology" in Biennial Review of Anthropology, ed. B. J. Siegel, Stanford, 1970.

Province of Freedom, London, 1969.

Anthropology of Law. London, New York, 1971.

"A Study of discrimination against persons born out of wedlock". SubCommission on Prevention of Discrimination and Protection of Minorities, United Nations, New York, 1967.

"Inheritance to property in Sierra Leone: an analysis of the law and problems involved". Sierra Leone Studies, No. 14, January 1969

"Sierra Leone" in Allott's Judical and Legal System of Africa, ed. A. N.

Allott, London 1970. 